\title{
Evidências de Isomorfismo nas Funções da Controladoria das Empresas Familiares Têxteis de Santa Catarina
}

Isomorphism Evidences in the Controlling Functions of Textiles Family Businesses in Santa Catarina

\section{Ilse Maria Beuren}

Doutora em Controladoria e Contabilidade na FEA/USP

Professora do Programa de Pós-Graduação em Ciências Contábeis da

Universidade Regional de Blumenau - FURB

Endereço: Rua Antônio da Veiga, 140 - Sala D 202 - Bairro Victor Konder

CEP 89012-900 - Blumenau/SC - Brasil

E-mail: ilse@furb.br

Telefone: (47) 33210565

\section{Gilson Jober Fachini}

Mestre em Ciências Contábeis na Universidade Regional de Blumenau

Endereço: Rua Antônio da Veiga, 140 - Sala D 202 - Bairro Victor Konder

CEP 89012-900 - Blumenau/SC - Brasil

E-mail: gilson.fachini@terra.com.br

Telefone: (47) 33210565

\section{Sabrina do Nascimento}

Mestre em Ciências Contábeis na Universidade Regional de Blumenau Endereço: Rua Antônio da Veiga, 140 - Sala D 202 - Bairro Victor Konder CEP 89012-900 - Blumenau/SC - Brasil

E-mail: sabnascimento@gmail.com

Telefone: (47) 33210565 


\title{
Resumo
}

O objetivo do estudo é verificar as evidências de isomorfismo nas funções da controladoria das empresas familiares têxteis de Santa Catarina. Pesquisa descritiva foi realizada por meio de levantamento ou survey, com abordagem qualitativa dos dados. A população da pesquisa compreende as 46 empresas familiares associadas ao Sintex de Blumenau, Santa Catarina. Ao controller dessas foi enviado um questionário para indicar o grau de importância das funções da controladoria em sua empresa, obteve-se 13 respostas, que compõem a amostra não aleatória. Para identificar as redes de isomorfismo presentes nas funções de controladoria investigadas, procedeu-se o cálculo de uma função ponderada com o software UNICET®. Os resultados da pesquisa mostram semelhanças no grau de importância atribuído às funções contábil, gerencial-estratégica, custos, tributária, proteção e controle de ativos, controles internos, controle de riscos, gestão da informação e controle operacional. Conclui-se que há evidências de isomorfismo na maioria das funções da controladoria das empresas familiares pesquisadas, considerando-se o grau de importância atribuído pelos respondentes às atividades distribuídas nas nove funções apontadas. As funções gerencial/estratégica, custos e contábil ocuparam as posições centrais da rede de isomorfismos denotando maior semelhança entre as empresas analisadas.

Palavras-chave: Isomorfismo. Funções da controladoria. Empresas familiares têxteis.

\begin{abstract}
The objective is to verify the evidence of isomorphism in the functions of controlling family textile business in Santa Catarina. Descriptive study was conducted by surveying or survey, with a qualitative approach. The survey includes 46 family businesses associated with Sintex Blumenau, Santa Catarina. The controller of these were sent a questionnaire to indicate the degree of importance in controlling the functions of your company, we obtained 13 responses, comprising the non-random sample. To identify the networks of isomorphism present in controllership functions investigated, we proceeded to calculate a weighted function with software UNICET ${ }^{\circledR}$. The survey results show similarities in the degree of importance attributed to accounting functions, managerial and strategic decisions, costs, tax, asset protection and control, internal controls, risk control, information management and operational control. We conclude that there is evidence of isomorphism in most of the functions of controlling family businesses surveyed, considering the degree of importance attributed by respondents to the activities distributed in nine functions mentioned. The functions managerial / strategic, cost accounting and occupied the central positions of the network isomorphisms showing greater similarity between the firms.
\end{abstract}

Key words:Isomorphism. Functions of the comptroller. Family businesses textiles.

\section{Introdução}

Abordagens sobre o papel da controladoria e suas funções nas organizações são elementos da pauta de diversas discussões acadêmicas. Há uma diversidade de entendimentos a respeito, muitas vezes decorrentes dos propósitos dos meios utilizados para a publicação dos escritos: livros didáticos genéricos ou específicos, trabalhos em anais de diferentes eventos científicos, artigos publicados em periódicos. Oliveira et al. (2007, p. 13) asseveram que a controladoria “[...] é uma atividade desenvolvida e divulgada somente a partir das últimas décadas, o que explica e justifica o fato de pairarem muitas dúvidas sobre o assunto [...]".

A ausência de uma definição convergente das funções da controladoria é percebida também em pesquisas que buscam repaginar esse foco em uma linha 
histórica. Ricardino Filho (1999, p. 4-5) adverte que "nas grandes e médias empresas, principalmente, a função não se delineou de forma absolutamente clara e por diversos anos pairou razoável incerteza sobre o assunto". Afirma ainda que "ao longo dos últimos quase oitenta anos, a atividade vem passando por um processo de amadurecimento que fica bastante visível quando se observam as definições dadas à função, desde os anos 20".

Borinelli (2006, p. 13) menciona que, "ainda que muito se fale sobre qual tem sido o papel desta nas organizações nas últimas décadas, não se encontram investigações científicas que, utilizando de uma abordagem empírica, evidenciassem, de fato, qual tem sido a realidade brasileira da controladoria". A partir desta constatação o autor realizou uma pesquisa, para "verificar se, e em que medida, os elementos que integram a Estrutura Conceitual Básica de Controladoria refletem as práticas de controladoria das 100 maiores empresas privadas, que operam no Brasil (BORINELLI, 2006, p. 30).

Como a estrutura conceitual básica da controladoria ainda está em fase de formação, é provável que tal ocorra também nas organizações. É neste sentido que se presume que as empresas possam estar copiando as práticas de controladoria que favoreçam o suporte informacional ao processo de gestão. Segundo Carpenter e Feroz (2001), isso decorre de uma série de pressões exógenas que influenciam a estrutura e as práticas organizacionais. A reprodução parcial ou total da práxis da controladoria entre empresas se consubstancia em mecanismo isomórfico, assim como preconizado na literatura de Teoria organizacional.

Dimaggio e Powell (1991) citam a existência de três tipos de mecanismos isomórficos: coercitivo, mimético, normativo. Os três tipos têm potencialidade para afetar as funções da controladoria em empresas com atividades de um mesmo setor econômico, ou eventualmente até de setores diferentes. Certamente empresas em ambientes semelhantes e com desafios parecidos favorecem o isomorfismo entre organizações, como é o caso de empresas familiares. Elas têm em comum a gestão da empresa por pessoas da família, a propriedade preponderante ou única do capital da empresa pertencer à família, os desafios da sucessão do comando da empresa, entre outros aspectos.

Cada um desses mecanismos isomórficos pode ser aplicado nas empresas isoladamente ou em conjunto nas funções típicas da controladoria. Com base no exposto formulou-se a seguinte pergunta de pesquisa: Quais são as evidências de isomorfismo nas funções da controladoria das empresas familiares têxteis de Santa Catarina? Para responder essa questão-problema o estudo objetiva verificar as evidências de isomorfismo nas funções da controladoria das empresas familiares têxteis de Santa Catarina.

A importância da indústria têxtil no Estado de Santa Catarina está no número de empresas deste setor estabelecidas e no expressivo número de empregos 
gerados. Destas, muitas são empresas familiares, independente da geração que está no comando ou do tempo de fundação da empresa. O Sindicato das Indústrias de Fiação, Tecelagem e do Vestuário (Sintex) de Blumenau congrega as empresas que formam o maior pólo têxtil do Estado. Conta atualmente com 46 empresas associadas, numa base territorial que inclui 18 municípios, emprega 65 mil pessoas, o que demonstra a importância do setor para a economia da região.

O fortalecimento das empresas por meio da associação a órgãos que visam defender interesses comuns e representá-las nos desafios conjuntos, seja junto a autoridades administrativas, judiciárias, legislativas e entidades civis em geral, sugere que também promovem iterações por meio de redes de conhecimentos administrativos e operacionais. Como a controladoria tem a missão de canalizar a sinergia das partes para maximizar o resultado global da empresa, pressupõese encontrar evidências de isomorfismo nas funções da controladoria dessas empresas.

A organização do estudo está estruturada em sete seções, iniciando com esta introdução. Na sequência faz uma incursão teórica no significado de isomorfismo, nas funções da controladoria preconizadas por em Borinelli (2006) e na concepção de empresas familiares. Após descreve o método e os procedimentos adotados para a realização desta pesquisa. Em seguida apresenta os resultados da pesquisa, com destaque ao perfil dos respondentes, características das empresas pesquisadas e evidências de isomorfismo nas funções da controladoria dessas empresas, além das conclusões do estudo realizado.

\section{Isomorfismo}

De acordo com Freitas (2005, p. 30), “o isomorfismo pode ser entendido como a busca da homogeneidade de estruturas, processos e ações no âmbito das organizações". O autor ainda assevera que "no âmbito da abordagem institucional, considera-se como fator preponderante para o isomorfismo a adequação social, que é a aquisição de um formato organizacional considerado legítimo em um determinado ambiente institucional".

Carpenter e Feroz (2001) ressaltam que o isomorfismo tem como origem a Teoria Institucional, a qual preconiza que as organizações apresentam tendências de acordo com as suas normas, tradições e influências sociais provenientes dos ambientes internos e externos. Os autores destacam que neste contexto é que se insere o isomorfismo, que busca a homogeneidade entre a estrutura e as práticas destas organizações para que sejam bem sucedidas ao conquistarem o apoio e legitimidade social.

Segundo Dimaggio e Powell (1991, p. 77), “o ambiente é um fator de homogeneização organizacional, na medida em que são difundidas práticas e for- 
mas de organização que são institucionalizadas pela comunidade de organizações pertencentes a um mesmo campo". As causas desta homogeneização, a que se chama de isomorfismo, podem ser diversas. Machado-da-Silva e Fonseca (1993, p. 30) aduzem que "o motivo que leva uma organização a adotar posturas isomórficas em relação aos líderes do seu campo organizacional é autodefesa diante de situações sem soluções geradas internamente, uma vez que a semelhança facilita as transações interorganizacionais".

Dimaggio e Powell (1991) apresentam três tipos de mecanismos isomórficos, resumidos no Quadro 1, com os indicadores em nível de campo organizacional, ou seja, em uma indústria, e em nível organizacional.

\section{Quadro 1 - Mecanismos isomórficos}

\begin{tabular}{|l|l|l|}
\hline $\begin{array}{l}\text { T i p o s d e } \\
\text { Isomorfismo }\end{array}$ & Nível Organizacional & Nível do Campo Organizacional \\
\hline Coercitivo & $\begin{array}{l}\text { Quanto mais dependentes são as } \\
\text { organizações, mais parecidas elas se } \\
\text { tornam. }\end{array}$ & $\begin{array}{l}\text { Quanto mais o campo depende de } \\
\text { um recurso único, maior o grau de } \\
\text { isomorfismo. }\end{array}$ \\
\cline { 2 - 4 } & $\begin{array}{l}\text { Quanto maior a centralização no } \\
\text { suprimento de recursos, maior a } \\
\text { dependência das outras organizações. }\end{array}$ & $\begin{array}{l}\text { Quanto maior a interação do campo com } \\
\text { o Estado, maior o grau deste mecanismo } \\
\text { de isomorfismo. }\end{array}$ \\
\hline \multirow{5}{*}{ Mimético } & $\begin{array}{l}\text { Quanto maior a incerteza, mais as } \\
\text { organizações tentarão copiar modelos } \\
\text { bem sucedidos. }\end{array}$ & $\begin{array}{l}\text { Quanto menoro número de organizações } \\
\text { modelo, mais rápido é o processo de } \\
\text { isomorfismo. }\end{array}$ \\
\cline { 2 - 4 } & $\begin{array}{l}\text { Quanto maior a ambiguidade das metas, } \\
\text { maior a probabilidade das organizações } \\
\text { imitarem as bem sucedidas. }\end{array}$ & $\begin{array}{l}\text { Quanto maior a incerteza tecnológica, } \\
\text { maior o padrão de isomorfismo. }\end{array}$ \\
\hline Normativo & $\begin{array}{l}\text { Quanto maior a participação dos } \\
\text { membros das organizações em } \\
\text { associações profissionais, maior a } \\
\text { similaridade entre as organizações. }\end{array}$ & $\begin{array}{l}\text { Quanto maior o profissionalismo no } \\
\text { campo, maior o grau de isomorfismo. }\end{array}$ \\
\hline
\end{tabular}

Fonte: adaptado de DiMaggio e Powell (1991).

O isomorfismo coercitivo é resultado tanto de pressões formais quanto de informais exercidas sobre a organização por outras organizações das quais ela depende (DIMAGGIO; POWELL, 1991). Além disso, também se enquadram neste mecanismo as pressões culturais da sociedade em que a organização está inserida. Em algumas situações a mudança organizacional está relacionada às imposições legais que obrigam a organização a adotar uma nova tecnologia ou a criação de uma nova função na empresa para o atendimento de uma obrigação prevista em lei. Também é possível encontrar este mecanismo de isomorfismo em organizações que expandem suas atividades por meio de aquisições, situação onde acontece a imposição da mudança organizacional nas empresas incorporadas.

De acordo com Dimaggio e Pawell (1991, p. 78), “a incerteza também 
constitui uma força poderosa que encoraja a imitação". Considerar outras organizações como exemplo pode ser entendido como uma resposta às incertezas que permeiam a organização. Este processo de isomorfismo entre as organizações pode acontecer por transferência de funcionários de uma mesma indústria, bem como pela contratação de consultorias externas que atendam a mais de uma empresa do mesmo setor. Esta afirmação tem como base a tendência de as organizações tomarem como modelo, em seu campo organizacional, outras organizações, que elas julgam ser mais legítimas ou bem-sucedidas. Chama-se este mecanismo de isomorfismo mimético.

$\mathrm{O}$ isomorfismo mimético "se encontra no pilar cognitivo-cultural, tendo como base de legitimação a sustentação cultural e a noção de conceitualmente correto" (OYADOMARI et al., 2008a, p. 17). De acordo com Carpenter e Feroz (2001), ele é utilizado quando as organizações enfrentam situações de indecisão e a melhor escolha não é clara, assim podem limitar a seleção de estruturas ou práticas utilizadas por outras grandes organizações que eles vêem como sendo bem sucedida no ambiente institucional no qual estão inseridos.

Quanto ao isomorfismo normativo, entende-se que na busca da profissionalização, onde os membros de uma classe profissional buscam normatizar seus métodos de trabalho para estabelecer uma base cognitiva e legitimar a autonomia da profissão, o desenvolvimento de isomorfismo naquela atividade profissional em um mesmo campo organizacional torna-se inevitável. Dois aspectos são fundamentais para o desenvolvimento deste mecanismo isomórfico. O primeiro é o apoio da educação formal e a regulamentação dos cursos de ensino superior. A segunda é a constituição de redes profissionais cujos associados trocam informações e conhecimentos que culminam com a padronização das atividades nas organizações onde atuam (DIMAGGIO; POWELL, 1991).

As funções de controladoria, bem como os profissionais que nela atuam, estão sujeitos aos três mecanismos de isomorfismo, considerando-se que o atendimento às legislações é parte do cotidiano da controladoria, e a exigência para o desempenho da profissão de possuir um curso de graduação em nível de graduação e pós-graduação. Não menos presente é o isomorfismo mimético, considerando a presença de consultorias, auditorias e a rotatividade de profissionais entre as empresas. Tolbert e Zucker (1999) destacam que as organizações tomam suas decisões após observar o comportamento de outras empresas, onde estas atuam como pré-testes na implementação de novas práticas institucionais. Entende-se que o incremento dessas condições tende a aumentar o isomorfismo entre as funções de controladoria, principalmente em empresas que atuam em um mesmo campo organizacional.

\section{Funções da controladoria}


Beuren (2002, p.21) afirma que "[...] a literatura não tem apresentado uma nítida definição de controladoria. As diversas abordagens têm seu foco mais voltado às capacidades requeridas para o exercício da função". Esta afirmação remete ao conceito de controladoria como unidade organizacional, responsável pela operacionalização das funções da controladoria nas organizações.

De forma geral, a controladoria é concebida como área da organização responsável pela reunião e disponibilização das informações utilizadas no processo decisório. Nesta perspectiva, Mosimann e Fisch (1999, p. 88) mencionam que "a controladoria pode ser conceituada como um conjunto de princípios, procedimentos e métodos oriundos das ciências de Administração, Economia, Psicologia, Estatística e, principalmente, Contabilidade, que se ocupam da gestão econômica, com o fim de orientá-la para a eficácia".

Segundo Almeida (2001), a controladoria pode ser entendida sob dois enfoques: a controladoria como área do conhecimento e a controladoria como unidade organizacional da empresa. A primeira ocupa-se do estabelecimento da base conceitual, os fundamentos, conceitos, princípios e métodos. Já a segunda, organizada como órgão administrativo com missão, funções e princípios delineados pelo modelo de gestão da organização.

Ainda que não se encontre consenso sobre o conceito de controladoria e tampouco sobre suas funções, parece ser convergente o posicionamento dos autores das mais diversas obras que a controladoria é essencial no processo de gestão. Seja ela um órgão formal da organização ou não, Mosimann e Fisch (1999, p. 90) argumentam que "o controller como gestor do sistema de informações, está em posição de exercer controle por meio do relato e da interpretação dos dados necessários à tomada de decisões".

Fernandes (2000, p.168) aduz que "a atividade de controladoria [...] não depende da existência de um órgão específico de controladoria [...], embora tal característica seja conveniente na maioria dos casos". Nesta linha, Borinelli (2006, p.190) assevera que a controladoria "se materializa, nas organizações por meio de diversas atividades que formam um conjunto de processos relativos às funções de controladoria".

Para o entendimento das funções da controladoria, Borinelli (2006, p. 126) explica que "uma função corresponde a um conjunto de atividades com propósitos comuns". O autor complementando que, "uma atividade corresponde a uma ação, a uma tarefa ou a um processo realizado por uma unidade organizacional que gera um produto ou serviço".

De acordo com Oliveira, Perez Jr. e Silva (2007, p. 19), "nas empresas de pequeno porte, que não dispõem ainda de adequada estrutura, o controller normalmente também seria responsável por outras atividades, como: informática, 
finanças, departamento de pessoal, etc.”. Destacam que esse cargo pode ainda receber outras denominações, como por exemplo, gerente administrativo-financeiro. Isto reforça a idéia de que as funções da controladoria nas organizações de menor porte acabam sendo executadas por outras unidades organizacionais, enquanto não houver a necessidade de uma unidade organizacional formalizada.

Nesta pesquisa assume-se o agrupamento de funções da controladoria proposto por Borinelli (2006, p. 135-), acrescida da função de controle operacional, cuja inclusão foi julgada conveniente para a consecução dos objetivos da pesquisa. Estas funções estão demonstradas no Quadro 2.

\section{Quadro 2 - Funções da controladoria}

\begin{tabular}{|c|c|}
\hline $\begin{array}{l}\text { F u n ç õ e s } \mathrm{de} \\
\text { controladoria }\end{array}$ & Descrição das Funções \\
\hline Função contábil & $\begin{array}{l}\text { Compreende o gerenciamento das atividades de contabilidade; o desenvolvimento, } \\
\text { implementação e manutenção do sistema contábil; a elaboração e análise das } \\
\text { demonstrações; o atendimento aos agentes de mercado; e o desenvolvimento das } \\
\text { políticas e procedimentos contábeis e de controle (KANITZ, 1976; BORINELLI, } \\
\text { 2006). }\end{array}$ \\
\hline \multicolumn{2}{|l|}{ Função gerencial/ } \\
\hline estratégica & $\begin{array}{l}\text { É função do controller desenvolver um sistema organizado, compreendendo contas, } \\
\text { políticas, registros e procedimentos para fornecer dados que possam ser analisados e } \\
\text { interpretados, a fim de auxiliar os gestores nas tomadas de decisões para alcançar as } \\
\text { metas da empresa e a eficácia organizacional. Subsidiar a etapa de planejamento, com } \\
\text { informações e instrumentos que permitam aos gestores avaliar o impacto das diversas } \\
\text { alternativas sobre o patrimônio e os resultados da organização. A função estratégica } \\
\text { da controladoria para apoiar a gestão deve necessariamente se projetar para o futuro, } \\
\text { coordenando, assessorando e consolidando os processos de elaboração e controle } \\
\text { dos planos empresariais, orçamentos e previsões (BEUREN, 2002; MARTIN, 2002; } \\
\text { PELEIAS, 2002; GIONGO e NASCIMENTO, 2005; BORINELLI, 2006). }\end{array}$ \\
\hline Função de custos & $\begin{array}{l}\text { Relaciona-se com as atividades de registrar, mensurar, controlar, analisar e avaliar os } \\
\text { custos da organização, que essencialmente são medidas monetárias dos sacrifícios com } \\
\text { os quais uma organização tem que arcar a fim de atingir seus objetivos econômicos. } \\
\text { Esta função inclui as análises gerenciais e estratégicas relativas ao lançamento de } \\
\text { produtos e serviços, aos resultados dos produtos e serviços, bem como linhas de } \\
\text { negócios, clientes, representantes ou qualquer outra forma de organização da área } \\
\text { comercial da organização (FIGUEIREDO e CAGGIANO, 1992; BORINELLI, } \\
\text { 2006). }\end{array}$ \\
\hline Função tributária & $\begin{array}{l}\text { Compreende o atendimento às obrigações legais, fiscais e acessórias previstas em leis } \\
\text { e normas tributárias, o que significa registrar, apurar e controlar impostos, tributos } \\
\text { e contribuições, além de elaborar o planejamento tributário da organização. Inclui } \\
\text { também a preparação e apresentação das declarações de impostos e obrigações } \\
\text { acessórias, a supervisão de todas as questões relacionadas, inclusive a condução de } \\
\text { um programa eficaz de gerenciamento de impostos (BEUREN, 2002; BORINELLI, } \\
\text { 2006). }\end{array}$ \\
\hline
\end{tabular}




\begin{tabular}{|c|c|}
\hline $\begin{array}{l}\text { F u n ç ã o d e } \\
\text { proteção e controle } \\
\text { de ativos }\end{array}$ & $\begin{array}{l}\text { "Compreende as atividades referentes a prover proteção aos ativos, como, por exemplo, } \\
\text { selecionar, analisar e contratar opções de seguros, além de controlá-los. Envolve ainda } \\
\text { as atividades de registrar e controlar todos os bens da organização" (BORINELLI, } \\
\text { 2006, p. 137). Oliveira et al. (2007, p. 84) asseveram que é objetivo da controladoria } \\
\text { "proteger os ativos da entidade, o que compreende bens e direitos". }\end{array}$ \\
\hline $\begin{array}{l}\text { F u n ç ã o } \quad \mathrm{d} \mathrm{e} \\
\text { controles internos }\end{array}$ & $\begin{array}{l}\text { "A função da controladoria como instrumento de controle administrativo é fundamental" } \\
\text { (OLIVEIRA et al., 2007, p. 84). O conjunto de controles internos tem como objetivo } \\
\text { verificar e assegurar o cumprimento às políticas e normas da organização, e permitir } \\
\text { a observância e o estrito cumprimento da legislação em vigor. A função de controles } \\
\text { internos "compreende as atividades referentes ao estabelecimento e monitoramento } \\
\text { do sistema de controles internos, destinado a proteger o patrimônio organizacional e } \\
\text { salvaguardar os interesses da entidade" (BORINELLI, 2006, p. 137) }\end{array}$ \\
\hline $\begin{array}{ll}\text { Função } & \text { d e } \\
\text { Controle } & \text { d e } \\
\text { Riscos } & \end{array}$ & $\begin{array}{l}\text { Para Fernandes (2000, p.203), "o papel da controladoria é o fornecimento de } \\
\text { informações que proporcionem coesão na busca de resultados e no cumprimento dos } \\
\text { objetivos, em especial a missão". O autor entende que "este movimento deve induzir } \\
\text { a inclusão de considerações sobre risco também nas atividades da controladoria". } \\
\text { Borinelli (2006, p.137) lembra que o controle de riscos é uma função recente } \\
\text { na literatura de controladoria, e aduz que esta função compreende "atividades } \\
\text { de identificar, mensurar, analisar, avaliar, divulgar e controlar os diversos riscos } \\
\text { envolvidos no negócio, bem como seus possíveis efeitos". }\end{array}$ \\
\hline $\begin{array}{l}\text { Função de Gestão } \\
\text { da Informação }\end{array}$ & $\begin{array}{l}\text { Mosimann e Fisch (1999, p.54) conceituam sistema de informação como "uma rede } \\
\text { de informações cujos fluxos alimentam o processo de tomada de decisões, não apenas } \\
\text { da empresa como um todo, mas também de cada área de responsabilidade". Arima } \\
\text { (2002, p.79) assevera que "a efetividade de um sistema de informação gerencial } \\
\text { adequado nas organizações, integrada à competência dos talentos humanos, tem sido } \\
\text { o diferencial para competitividade empresarial". Borinelli (2006, p. 139) cita que "faz } \\
\text { parte das atividades de controladoria desenvolver, implementar e gerir os sistemas } \\
\text { de informações, no que tange às informações contábeis, econômicas, financeiras e } \\
\text { patrimoniais". }\end{array}$ \\
\hline $\begin{array}{l}\text { FunçãodeControle } \\
\text { Operacional }\end{array}$ & $\begin{array}{l}\text { Almeida, Parisi e Pereira (2001) relacionam o controle como um processo de gestão } \\
\text { da controladoria com a utilização de sistemas de informação orientados à avaliação } \\
\text { de desempenho e de resultados. Controle "envolve detectar o que está acontecendo } \\
\text { na operação, replanejando se necessário, e intervindo de modo a impor novos planos" } \\
\text { (SLACK; CHAMBERS; JOHNSTON, 2002, p.339). A função de controle operacional } \\
\text { está alicerçada no acompanhamento da execução do orçamento empresarial, bem como } \\
\text { no acompanhamento e controle dos indicadores relativos aos processos internos. }\end{array}$ \\
\hline
\end{tabular}

Fonte: elaborado com base em Borinelli (2006).

As nove funções de controladoria elencadas no Quadro 2 demonstram nas suas descrições posições semelhantes de diversos autores sobre cada uma das funções. Estas semelhanças sugerem concordância com a afirmação de Dimmagio e Powell (1991), quando discorrem sobre isomorfismo normativo e argumentam que a educação formal e a busca da profissionalização servem de catalizadores para a existência de mecanismos isomórficos.

\section{Conceituação de empresa familiar}


Para Lodi (1996, p. 6), "a empresa familiar é aquela em que a consideração da sucessão da diretoria está ligada ao fator hereditário e onde os valores institucionais da firma identificam-se com um sobrenome ou com a figura de um fundador". O autor ainda afirma que "o conceito de empresa familiar nasce geralmente com a segunda geração de dirigentes".

Segundo Casillas, Fernandez e Sanchez (2007), três características fundamentam a delimitação das empresas familiares: a) a propriedade ou o controle que a família tem sobre a empresa; b) o poder exercido sobre a empresa, normalmente pelo trabalho e cargos ocupados por membros da família; c) a predisposição de transferir a empresa a futuras gerações e a efetivação disso na inserção dessa nova geração na própria empresa.

De acordo com Petry (2005, p. 106), "uma empresa se caracteriza como familiar por ter em sua gestão a família proprietária, não apontando restrições ao fato de já ter ocorrido sucessão". O autor aduz também que o conceito de empresa familiar "se baseia na premissa de que as famílias, tendo ou não representantes na gestão, exerçam influência sobre a missão e os objetivos da organização a partir dos seus próprios interesses".

Para este estudo, adotou-se como premissa o enquadramento de uma empresa como familiar mesmo em sua primeira geração, ou seja, antes de qualquer processo sucessório. Este conceito se fundamenta na afirmação de que mesmo na geração dos sócios fundadores, é forte a influência da cultura das famílias controladoras sobre a missão e os objetivos organizacionais (PETRY, 2005).

Casillas, Fernandez e Sanchez (2007, p. 12) destacam que "no âmbito da prática profissional, no mundo da empresa familiar, o principal critério de classificação das empresas familiares consiste da relação com a geração que está na empresa". Os autores citam que uma empresa pode ser considerada de primeira geração "quando ela é de propriedade da família e dirigida pelo fundador ou fundadores". Advertem que alguns autores argumentam que estas empresas somente podem ser consideradas familiares se algum membro da geração seguinte já estiver participando efetivamente da empresa.

As empresas de segunda geração são caracterizadas pela participação na gestão de filhos ou sobrinhos do fundador ou fundadores. Para Casillas, Fernandez e Sanchez (2007, p. 13), “a propriedade costuma estar nas mãos de vários irmãos. O controle, no entanto, pode estar tanto nas mãos da família como nas mãos de profissionais externos (empresa familiar profissionalizada) ou até mesmo compartilhado entre família e externos".

Casillas, Fernandez e Sanchez (2007, p. 14) mencionam que empresas de terceira geração ou posteriores "são empresas familiares em que os netos [...] do fundador são os principais proprietários e diretores". Oro (2006) destaca que na terceira geração, ou mais, as empresas normalmente começam a aventar a 
possibilidade de uma gestão profissionalizada. Oro (2006, p 43) lembra, ainda, que "algumas empresas já passaram por esta fase e são propriedades da quarta, quinta ou sexta geração".

\section{Método e Procedimentos da Pesquisa}

Esta pesquisa caracteriza-se como descritiva, do tipo levantamento e com abordagem qualitativa. Conforme Cervo e Bervian (2002, p. 66), “a pesquisa descritiva observa, analisa e correlaciona fatos ou fenômenos (variáveis) sem manipulá-los". Afirmam ainda que a pesquisa descritiva "procura descobrir, com a previsão possível, a frequência com que um fenômeno ocorre, sua relação e conexão com outros, sua natureza e características".

Em relação à pesquisa de levantamento ou survey, Cervo e Bervian (2002, p. 48) ressaltam que "[...] é a forma mais adequada para coletar dados, pois possibilita medir com melhor exatidão o que se deseja". A população considerada na pesquisa é constituída por 46 empresas têxteis associadas ao Sindicato das Indústrias de Fiação, Tecelagem e Vestuário (Sintex) de Blumenau, Santa Catarina. A amostra é formada pelas 13 empresas que responderam à pesquisa.

Como instrumento de pesquisa foi utilizado um questionário com perguntas fechadas. Segundo Martins e Theóphilo (2007, p. 90), "é um importante e popular instrumento de coleta de dados para uma pesquisa social". Os autores ainda explicam que "trata-se de um conjunto ordenado e consistente de perguntas a respeito de variáveis e situações que se deseja medir ou descrever". O questionário utilizado foi estruturado em duas partes, sendo a primeira com doze perguntas destinadas a identificar o perfil do respondente e as características da empresa.

A segunda parte do instrumento de pesquisa buscou averiguar o grau de importância atribuído nas empresas, segundo os controllers, às funções da controladoria. Estas foram estruturadas em nove grupos, cada grupo relativo a uma função, que juntos totalizam trinta e cinco perguntas respondidas por meio de uma escala do tipo Likert de 1 (um) a 5 (cinco), sendo o 1 (um) caracterizado como uma função menos importante e 5 (cinco) como uma função mais importante.

$\mathrm{Na}$ análise dos dados priorizou-se a abordagem qualitativa. Martins e Theóphilo (2007, p. 136) aduzem que "a pesquisa qualitativa tem como preocupação central descrições, compreensões e interpretações dos fatos ao invés de medições". Os autores complementam afirmando que "desta forma o pesquisador procura encontrar nexos entre diversas variáveis relacionadas ao seu objeto de estudo".

Após a identificação de isomorfismos entre as funções de controladoria nas empresas respondentes da pesquisada, promoveu-se a título complementar a averiguação das redes de isomorfismos das funções de controladoria. Estas foram calculadas a partir de uma função ponderada com base nas respostas obtidas na 
segunda parte com auxílio do software UNICET®. Desse modo consegue-se melhor visualizar em quais funções da controladoria mais se concentram os isomorfismos.

Como limitações da pesquisa destacam-se inicialmente a pequena quantidade de respostas ao questionário. Outra limitação diz respeito à dependência das respostas informadas, sem uma verificação in loco do grau de importância das funções da controladoria nas empresas. É possível, também, que os respondentes tenham atribuído grau de importância a alguma função planejada, mas ainda não efetivada na organização.

\section{Descrição e Análise dos Dados}

Nesta seção relacionam-se os dados encontrados na pesquisa buscando evidenciar a existência ou não de isomorfismos quanto às funções de controladoria nas empresas pesquisadas.

\subsection{Perfil dos Respondentes da Pesquisa}

Na Tabela 1 apresenta-se o perfil dos respondentes, destacando-se o gênero, a idade e o grau de escolaridade.

\section{Tabela 1 - Perfil dos respondentes}

\begin{tabular}{|c|c|c|c|}
\hline Características & Opções e Faixas & $n^{\circ}$ & $\%$ \\
\hline \multirow{2}{*}{ Gênero do respondente } & Feminino & 2 & $15.4 \%$ \\
\hline & Masculino & 11 & $84.6 \%$ \\
\hline \multirow{5}{*}{ Idade do respondente. } & De 20 a 30 anos & 4 & $30.8 \%$ \\
\hline & De 30 a 40 anos & 3 & $23.1 \%$ \\
\hline & De 40 a 50 anos & 4 & $30.8 \%$ \\
\hline & Acima de 50 anos & $\mathbf{0}$ & $0.0 \%$ \\
\hline & Não responderam & 2 & $15.4 \%$ \\
\hline \multirow{6}{*}{ Grau de escolaridade } & 20 grau completo & 1 & $7.7 \%$ \\
\hline & 30 grau incompleto & 3 & $23.1 \%$ \\
\hline & 30 grau completo & 5 & $38.5 \%$ \\
\hline & Especialização & 4 & $30.8 \%$ \\
\hline & Mestrado & $\mathbf{0}$ & $0.0 \%$ \\
\hline & Doutorado & $\mathbf{0}$ & $0.0 \%$ \\
\hline
\end{tabular}

Fonte: Dados da pesquisa.

Na Tabela 1 percebe-se uma predominância de controllers do gênero masculino, representando $84,6 \%$ dos respondentes da pesquisa. A faixa etária predominante é de respondentes com até 40 anos idade, ou seja, somadas as duas faixas etárias iniciais ( 20 a 30 anos e 30 a 40 anos), tem-se $53,9 \%$ dos respondentes. 
Dos respondentes que estão situados na faixa etária de 40 a 50 anos, apenas um não tem curso superior completo. Cabe também salientar que as respondentes do gênero feminino têm como menor grau de formação o $3^{\circ}$ grau completo.

\subsection{Caracterização das Empresas Pesquisadas}

Na Tabela 2 apresenta-se a caracterização das empresas pesquisadas, ressaltando-se o número de funcionários, a receita operacional bruta, o tempo de fundação da empresa, a geração familiar predominante, a idade média dos equipamentos, o percentual de investimento anual em tecnologia e o percentual de investimento anual em sistemas de informação.

Tabela 2 - Caracterização das empresas pesquisadas

\begin{tabular}{|c|c|c|c|}
\hline Características & Opções e Faixas & $\mathbf{n}^{\circ}$ & $\%$ \\
\hline \multirow[t]{4}{*}{ Número de funcionários } & Até 19 & 4 & $30.8 \%$ \\
\hline & De 20 a 99 & 2 & $15.4 \%$ \\
\hline & De 100 a 499 & 6 & $46.2 \%$ \\
\hline & Acima de $\mathbf{5 0 0}$ & 1 & $7.7 \%$ \\
\hline \multirow[t]{4}{*}{ Receita Operacional Bruta } & Até 1,2 milhão & 4 & $30.8 \%$ \\
\hline & De $\mathrm{R} \$ 1,2$ à $\mathrm{R} \$ 10,5$ milhões & 4 & $30.8 \%$ \\
\hline & De R\$ 10,5 à R\$ 60 milhões & 5 & $38.5 \%$ \\
\hline & Acima de R\$ 60 milhões & 0 & $0.0 \%$ \\
\hline \multirow[t]{5}{*}{ Tempo de fundação da empresa } & Até 10 anos & 2 & $15.4 \%$ \\
\hline & De 10 a 20 anos & 9 & $69.2 \%$ \\
\hline & De 20 a 50 anos & 2 & $15.4 \%$ \\
\hline & De 50 a 100 anos & 0 & $0.0 \%$ \\
\hline & Acima de 100 anos & 0 & $0.0 \%$ \\
\hline \multirow{5}{*}{$\begin{array}{l}\text { Qual a geração familiar que predomina na gestão } \\
\text { atual? }\end{array}$} & Primeira geração (sócios fundadores) & 8 & $61.5 \%$ \\
\hline & Segunda geração & 3 & $23.1 \%$ \\
\hline & Terceira geração & 0 & $0.0 \%$ \\
\hline & Gestão contratada & 0 & $0.0 \%$ \\
\hline & Gestão mista (familiar/contratada) & 2 & $15.4 \%$ \\
\hline \multirow{6}{*}{$\begin{array}{l}\text { Qual a idade média dos equipamentos que } \\
\text { compõem o parque fabril? }\end{array}$} & Menos de dois anos & 3 & $23.1 \%$ \\
\hline & De dois a cinco anos & 4 & $30.8 \%$ \\
\hline & De cinco a dez anos & 5 & $38.5 \%$ \\
\hline & De dez a quinze anos & 1 & $7.7 \%$ \\
\hline & De quinze a vinte anos & 0 & $0.0 \%$ \\
\hline & Acima de vinte anos & 0 & $0.0 \%$ \\
\hline Qual o percentual de investimento anual em & Menos de $2 \%$ & 0 & $0.0 \%$ \\
\hline tecnologia em relação aos equipamentos que & De $2 \%$ a $5 \%$ & 2 & $15.4 \%$ \\
\hline
\end{tabular}




\begin{tabular}{|l|l|l|l|}
\hline \hline \multirow{4}{*}{ compõem o ativo imobilizado? } & De 5\% a 8\% & 4 & $30.8 \%$ \\
\cline { 2 - 4 } & De $8 \%$ a $10 \%$ & 2 & $15.4 \%$ \\
\cline { 2 - 4 } & De $10 \%$ a $20 \%$ & 5 & $38.5 \%$ \\
\cline { 2 - 4 } & Acima de $20 \%$ & 0 & $0.0 \%$ \\
\hline \multirow{2}{*}{$\begin{array}{l}\text { Qual o percentual de investimento anual em } \\
\text { sistemas de informação em relação à receita } \\
\text { operacional bruta? }\end{array}$} & Menos de $2 \%$ & 4 & $30.8 \%$ \\
\cline { 2 - 4 } & De 2\% a 5\% & 5 & $38.5 \%$ \\
\cline { 2 - 4 } & De 5\% a 8\% & 0 & $0.0 \%$ \\
\cline { 2 - 4 } & De 8\% a $10 \%$ & 1 & $7.7 \%$ \\
\cline { 2 - 4 } & De $10 \%$ a $20 \%$ & 3 & $23.1 \%$ \\
\cline { 2 - 4 } & Acima de $20 \%$ & 0 & $0.0 \%$ \\
\hline
\end{tabular}

Fonte: Dados da pesquisa.

Para a pergunta sobre o número de funcionários foi utilizada a classificação do SEBRAE, que estabelece faixas de 0 a 19 funcionários (micro empresa); de 20 a 99 funcionários (pequena empresa); de 100 a 499 funcionários (médio porte) e acima de 500 funcionários (grande porte). As empresas foram ainda classificadas com relação à geração de receita operacional bruta anual. Para esta pergunta foi utilizado o critério de classificação do BNDES: até R \$ 1,2 milhão (micro empresa); de $\mathrm{R} \$ 1,2$ a R \$ 10,5 milhões (pequena empresa); de R \$ 10,5 a 60 milhões (médio porte); e acima de R $\$ 60$ milhões (grande porte).

$\mathrm{Na}$ Tabela 2 observa-se que quanto ao número de funcionários, apenas uma empresa está classificada na faixa acima de 500 funcionários. O controller desta empresa declarou ter $3^{\circ}$ grau incompleto, o que surpreende. Esperava-se que em empresas de maior porte, a pessoa ocupante desse cargo tivesse pelo menos o $3^{\circ}$ grau completo. Nas empresas classificadas na faixa de 100 a 499 funcionários, apenas um respondente não possui o $3^{\circ}$ grau completo, sendo que dois dos respondentes desta faixa possuem especialização.

As empresas pesquisadas são micro, pequenas e de médio porte. Das classificadas como micro empresas, todas possuem até 19 funcionários e três dos respondentes têm de 20 a 30 anos. Das empresas classificadas como de pequeno porte, ou seja, receita operacional bruta entre $\mathrm{R} \$ 1,2$ e 10,5 milhões, duas possuem de 20 a 99 funcionários e duas de 100 a 499. Os quatro respondentes deste grupo possuem $3^{\circ}$ grau completo. As empresas classificadas como de médio porte, todas possuem mais de 100 funcionários.

No item relacionado ao tempo de fundação, tem-se o objetivo de avaliar possíveis isomorfismos entre empresas com características comuns e tempos de fundação diferentes. Pressume-se que as empresas com menor tempo de fundação procuram igualar suas funções de controladoria àquelas com maior tempo de mercado.

As duas empresas com até dez anos de fundação estão classificadas como 
micro empresas e possuem até 19 funcionários. Com relação às empresas classificadas entre 10 e 20 anos de fundação, uma é classificada como micro empresa, quatro como empresas de pequeno porte e quatro como empresas de médio porte.

Em relação à geração familiar que predomina na gestão atual, buscou-se verificar se a geração ou a profissionalização da gestão exercem alguma influência no grau de isomorfismo nas funções da controladoria. As empresas de primeira geração, que representaram a maioria das respondentes, encontram-se todas com classificações já vistas nos itens anteriores, não sendo possível qualquer inferência sobre estes dados. Porém, sobre as empresas de segunda geração é possível dizer que todas possuem tempo de fundação entre 10 e 20 anos e seus respondentes tem $3^{\mathrm{o}}$ grau completo. Sobre as empresas de gestão mista, as duas são de médio porte, possuem de 100 a 499 funcionários e tem de 10 a 20 anos de fundação.

Buscou-se, também, averiguar se há algum isomorfismo entre as funções de controladoria e a idade média dos equipamentos fabris. A finalidade é investigar se empresas com o mesmo perfil de idade de equipamentos possuem também perfis semelhantes quanto às funções de controladoria. Nota-se que $92,3 \%$ das empresas informaram que seus equipamentos fabris possuem menos de 10 anos de utilização, sendo que $53,9 \%$ das empresas têm equipamentos com até 5 anos de uso. Das empresas que possuem equipamentos com menos de 5 anos de utilização, apenas uma tem menos de 10 anos de fundação, e quatro delas possuem entre 100 e 499 funcionários e estão classificadas como empresas de médio porte. A empresa cujos equipamentos têm entre 10 e 15 anos de utilização, tem acima de 500 funcionários, de 20 a 50 anos de fundação, está na primeira geração e é classificada como empresa de pequeno porte.

Sobre o percentual de investimento anual em tecnologia em relação aos equipamentos que compõem o ativo imobilizado, das empresas que informaram investir entre $10 \%$ e $20 \%$, todas possuem tempo de fundação superior a 10 anos, uma é classificada como micro empresa, uma como de pequeno porte e três delas como empresas de médio porte. As duas empresas de gestão mista estão classificadas neste grupo de investimentos.

Corroborando a informação anterior, uma das empresas que informou investir de $2 \%$ a $5 \%$, é a mesma empresa que possui equipamentos com 10 a 15 anos de utilização. De forma contraditória, uma empresa que afirmou possuir equipamentos com idade entre 2 e 5 anos, afirmou investir entre $2 \%$ e $5 \%$ em tecnologia.

Com relação ao investimento anual em sistemas de informação, as três empresas que afirmaram investir de $10 \%$ a $20 \%$ da receita operacional bruta estão classificadas como empresas de médio porte, possuem de 100 a 499 funcionários, têm tempo de fundação entre 10 e 20 anos e duas delas são empresas de gestão 
mista. As demais faixas de investimento têm empresas com diferentes perfis, não permitindo qualquer inferência.

\subsection{Isomorfismo nas Funções de Controladoria das Empresas Pesquisadas}

Primeiramente buscou-se caracterizar as empresas respondentes e classificá-las em grupos. A partir desse momento apresentam-se as respostas relativas às funções da controladoria. Na Tabela 3 consta o grau de importância atribuído pelas 13 empresas às funções classificadas como contábeis, sendo 1 menos importante e 5 mais importante.

Tabela 3 - Função contábil

\begin{tabular}{|l|l|l|l|l|l|l|l|}
\hline Funções/Pontuação & Não Resp. & 1 & 2 & 3 & 4 & 5 & Total \\
\hline $\begin{array}{l}\text { Gerenciar as atividades do processamento contábil, } \\
\text { implementar e manter todos os registros contábeis }\end{array}$ & 0 & 1 & 0 & 1 & 3 & 8 & 13 \\
\hline Elaborar as demonstrações contábeis & & & & & \\
\hline $\begin{array}{l}\text { Atender aos agentes de mercado (stakeholders) em suas } \\
\text { demandas informacionais }\end{array}$ & 0 & 0 & 1 & 2 & 4 & 6 & 13 \\
\hline $\begin{array}{l}\text { Proceder à análise interpretativa das demonstrações } \\
\text { contábeis }\end{array}$ & 1 & 0 & 0 & 1 & 3 & 8 & 13 \\
\hline $\begin{array}{l}\text { Desenvolver políticas e procedimentos contábeis e de } \\
\text { controle }\end{array}$ & 1 & 0 & 0 & 1 & 6 & 5 & 13 \\
\hline
\end{tabular}

Fonte: Dados da pesquisa.

Na Tabela 3 observa-se que apenas uma das empresas respondentes declarou que o gerenciamento das atividades de contabilidade e a elaboração das demonstrações têm pouca importância na organização. Esta empresa é de médio porte, tem de 100 a 499 funcionários, tempo de fundação de 10 a 20 anos e o respondente cursou uma especialização.

Em discordância a esta empresa, em conformidade com Kanitz (1976) e Borinelli (2006), 11 empresas declararam que gerenciar as atividades de contabilidade e analisar as demonstrações contábeis são funções de grande importância, bem como 12 empresas demonstraram alta importância para a elaboração das demonstrações contábeis, representando $92,3 \%$ da amostra.

Na Tabela 4 demonstra-se o grau de importância da função gerencial/ estratégica para as 13 empresas respondentes. 
Tabela 4 - Função gerencial / estratégica

\begin{tabular}{|l|l|l|l|l|l|l|l|}
\hline Funções/Pontuação & $\begin{array}{l}\text { N ã } \\
\text { Resp. }\end{array}$ & 1 & 2 & 3 & 4 & 5 & Total \\
\hline $\begin{array}{l}\text { Prover informações de natureza, patrimonial, econômica, } \\
\text { financeira e não-financeira ao processo de gestão }\end{array}$ & 0 & 0 & 0 & 1 & 5 & 7 & 13 \\
\hline $\begin{array}{l}\text { Coordenar os esforços dos gestores para que se obtenha } \\
\text { sinergia no processo de alcance dos objetivos empresariais }\end{array}$ & 0 & 0 & 0 & 1 & 3 & 9 & 13 \\
\hline $\begin{array}{l}\text { Coordenar, assessorar e consolidar os processos de elaboração } \\
\text { dos planos empresariais, orçamentos e previsões }\end{array}$ & 0 & 0 & 0 & 2 & 2 & 9 & 13 \\
\hline $\begin{array}{l}\text { Criar condições para a realização do controle, através do } \\
\text { acompanhamento dos planos e das decisões tomadas. }\end{array}$ & 0 & 0 & 1 & 2 & 1 & 9 & 13 \\
\hline $\begin{array}{l}\text { Auxiliar na definição de métodos e processos para medição } \\
\text { do desempenho das áreas organizacionais }\end{array}$ & 0 & 0 & 0 & 3 & 5 & 5 & 13 \\
\hline $\begin{array}{l}\text { Auxiliar na definição e gestão de preços de transferência } \\
\text { gerenciais }\end{array}$ & 1 & 0 & 0 & 1 & 6 & 5 & 13 \\
\hline $\begin{array}{l}\text { Realizar estudos sobre análise de viabilidade econômica de } \\
\text { projetos de investimento }\end{array}$ & 0 & 1 & 0 & 1 & 1 & 10 & 13 \\
\hline Realizar estudos especiais de natureza contábil-econômica & 0 & 1 & 0 & 1 & 8 & 3 & 13 \\
\hline $\begin{array}{l}\text { Desenvolver condições para a realização da gestão econômica } \\
\text { e proceder à avaliação econômica }\end{array}$ & 0 & 0 & 1 & 2 & 5 & 5 & 13 \\
\hline
\end{tabular}

Fonte: Dados da pesquisa.

Sobre as funções gerenciais/estratégicas, uma empresa atribuiu-lhes baixa importância, considerando importante somente a função de coordenação, assessoramento e consolidação dos processos de elaboração dos planos empresariais, orçamentos e previsões. Esta empresa tem de 100 a 499 funcionários, tem tempo de fundação entre 10 e 20 anos, a gestão é mista e está classificada como empresa de médio porte. A importância declarada por esta empresa para as funções contábeis também não atingiu a nota máxima.

A função relacionada a coordenar os esforços dos gestores para que se obtenha sinergia no processo de alcance dos objetivos empresariais, teve a maior concordância entre as empresas, denotando a importância do alcance dos objetivos na visão dos respondentes. As funções com maior pontuação estão em linha com as descritas na teoria para a função estratégica da controladoria, que é o de apoiar a gestão na projeção do futuro, coordenando, assessorando e consolidando os processos de elaboração e controle dos planos empresariais, orçamentos e previsões (BEUREN, 2002; MARTIN, 2002; PELEIAS, 2002; GIONGO e NASCIMENTO, 2005; BORINELLI, 2006).

Na Tabela 5 apresenta-se o grau de importância da função de custos na empresa, de acordo com a visão dos respondentes da pesquisa. 
Tabela 5 - Função de custos

\begin{tabular}{|l|l|l|l|l|l|l|l|}
\hline Funções/Pontuação & Não Resp. & 1 & 2 & 3 & 4 & 5 & Total \\
\hline $\begin{array}{l}\text { Realizar análises gerenciais e estratégicas referentes à } \\
\text { viabilidade de lançamentos de bens e serviços }\end{array}$ & 0 & 0 & 1 & 1 & 2 & 9 & 13 \\
\hline Gerenciar o custeio de bens e serviços & 0 & 0 & 0 & 1 & 3 & 9 & 13 \\
\hline $\begin{array}{l}\text { Analisar a rentabilidade de clientes, linhas de negócios, } \\
\text { regiões }\end{array}$ & 0 & 0 & 0 & 2 & 2 & 9 & 13 \\
\hline Analisar atividades que agregam / não agregam valor & 0 & 0 & 1 & 0 & 2 & 10 & 13 \\
\hline Desenvolver o sistema de custos & 0 & 0 & 0 & 1 & 3 & 9 & 13 \\
\hline Formar o preço de venda dos produtos / serviços & 0 & 0 & 0 & 1 & 2 & 10 & 13 \\
\hline
\end{tabular}

Fonte: Dados da pesquisa.

Borinelli (2006, p. 137) afirma que a função de custos da controladoria "compreende as atividades de registrar, mensurar, controlar, analisar e avaliar os custos da organização". A afirmação defendida por Borinelli está em consonância com o resultado encontrado nestas respostas. Oito empresas atribuíram nota máxima (5) a todos os itens relacionados à função de custos. Estas empresas também atribuíram notas elevadas (4 ou 5) aos itens da função gerencial / estratégica.

Apenas uma empresa da amostra declarou que a função custo tem importância menor, atribuindo notas 2 e 3 para as funções apresentadas. Todas as demais atribuíram notas relevantes para a função de custos da controladoria. A empresa que atribui as notas de menor importância também atribui pouca importância para a função gerencial/estratégica. É uma empresa de gestão mista, de médio porte, possui de 100 a 499 funcionários e tem de 10 a 20 anos de fundação.

Na Tabela 6 mostra-se o grau de importância atribuída pelos respondentes às atividades desenvolvidas nas empresas, relacionadas à função tributária.

\section{Tabela 6 - Função tributária}

\begin{tabular}{|l|l|l|l|l|l|l|l|}
\hline Funções/Pontuação & Não Resp. & 1 & 2 & 3 & 4 & 5 & Total \\
\hline $\begin{array}{l}\text { Atender obrigações legais, fiscais e acessórias previstas em } \\
\text { leis e normas tributárias }\end{array}$ & 0 & 0 & 2 & 0 & 5 & 6 & 13 \\
\hline Elaborar o planejamento tributário da organização & 0 & 0 & 1 & 0 & 4 & 8 & 13 \\
\hline
\end{tabular}

Fonte: Dados da pesquisa.

Conforme Tabela 6, duas das empresas respondentes atribuíram pouca importância à função tributária de registrar, apurar e controlar impostos, tributos e contribuições. Estas empresas destoam do resultado apresentado por Borinelli (2006, p. 137) em sua pesquisa sobre a estrutura conceitual básica de controladoria, quando assevera que a função tributária da controladoria "compreende as atividades relativas à Contabilidade Tributária (ou Fiscal), ou seja, atender às obrigações legais, fiscais e acessórias previstas em leis e normas tributárias, o que 
significa registrar, apurar e controlar impostos, tributos e contribuições”.

Poder-se-ia esperar que estas empresas fossem classificadas como micro empresas ou de pequeno porte e que não possuíssem estrutura interna para a consecução destas funções. Porém, as duas empresas são de médio porte, uma tem de 100 a 499 funcionários e a outra acima de 500 funcionários. As demais empresas da amostra declararam níveis 4 e 5 de importância para a função tributária.

A Tabela 7 evidencia o grau de importância conferido nas empresas à função de proteção e controle de ativos.

Tabela 7 - Função de proteção e controle de ativos

\begin{tabular}{|l|l|l|l|l|l|l|l|}
\hline Funções/Pontuação & Não Resp. & 1 & 2 & 3 & 4 & 5 & Total \\
\hline $\begin{array}{l}\text { Selecionar, analisar e contratar opções de seguros, além de } \\
\text { controlá-los }\end{array}$ & 0 & 0 & 1 & 3 & 7 & 2 & 13 \\
\hline Registrar e controlar todos os bens da organização & 0 & 0 & 0 & 3 & 6 & 4 & 13 \\
\hline
\end{tabular}

Fonte: Dados da pesquisa.

Com relação às funções de proteção e controle de ativos, apenas uma empresa declarou baixa importância a essas funções. Esta mesma empresa informou pouca importância nos processos operacionais da função contábil, porém atribuiu notas elevadas às funções de envolvimento estratégico. Infere-se, portanto, que nesta empresa a controladoria tem papel mais estratégico do que operacional.

É importante frisar que diferentemente das outras funções, o maior número de respondentes das empresas apontou importância 4 para as funções de proteção e controle de ativos. Segundo Oliveira et al. (2007, p. 84), é objetivo da controladoria "proteger os ativos da entidade, o que compreende bens e direitos".

O grau de importância atribuído às funções relacionadas aos controles internos e sua consecução pela controladoria está demonstrado na Tabela 8.

Tabela 8 - Função de controles internos

\begin{tabular}{|l|l|l|l|l|l|l|l|}
\hline Funções/Pontuação & Não Resp. & 1 & 2 & 3 & 4 & 5 & Total \\
\hline $\begin{array}{l}\text { Estabelecer e monitorar o sistema de controles internos, } \\
\text { destinado a proteger o patrimônio e salvaguardar os interesses } \\
\text { da entidade }\end{array}$ & 0 & 0 & 0 & 3 & 8 & 2 & 13 \\
\hline $\begin{array}{l}\text { Verificar e assegurar o cumprimento às políticas e normas da } \\
\text { companhia, incluindo o código de ética nas relações comerciais } \\
\text { e profissionais }\end{array}$ & 0 & 0 & 0 & 2 & 5 & 6 & 13 \\
\hline $\begin{array}{l}\text { Permitir a observância e o estrito cumprimento da legislação } \\
\text { em vigor }\end{array}$ & 1 & 0 & 0 & 1 & 2 & 9 & 13 \\
\hline
\end{tabular}

Fonte: Dados da pesquisa.

De acordo com Oliveira et al. (2007, p. 84), "a função da controladoria como instrumento de controle administrativo é fundamental”. Argumentam ainda 
que "um sistema de contabilidade que não esteja apoiado em um controle interno é, até certo ponto, inútil, uma vez que não é possível confiar nas informações contidas em seus relatórios". Verifica-se nas respostas que a importância destas funções nas empresas respalda a afirmação acima. Nenhuma empresa atribuiu baixa importância às funções relacionadas aos controles internos.

As respostas referentes ao grau de importância atribuído à função de controles de riscos estão expostas na Tabela 9.

Tabela 9 - Função de controles de riscos

\begin{tabular}{|l|l|l|l|l|l|l|l|}
\hline Funções/Pontuação & Não Resp. & 1 & 2 & 3 & 4 & 5 & Total \\
\hline $\begin{array}{l}\text { Identificar, mensurar, analisar, avaliar, divulgar e controlar } \\
\text { os diversos riscos envolvidos no negócio, bem como seus } \\
\text { possíveis efeitos }\end{array}$ & 0 & 0 & 1 & 1 & 3 & 8 & 13 \\
\hline $\begin{array}{l}\text { Definir planos de melhoria que conduzam a empresa a um } \\
\text { ambiente de controle adequado }\end{array}$ & 0 & 1 & 1 & 0 & 4 & 7 & 13 \\
\hline
\end{tabular}

Fonte: Dados da pesquisa.

Borinelli (2006, p.137) salienta que o controle de riscos é uma função recente na literatura de controladoria, e aduz que esta função compreende "atividades de identificar, mensurar, analisar, avaliar, divulgar e controlar os diversos riscos envolvidos no negócio, bem como seus possíveis efeitos". Mesmo sendo uma função recente na literatura de controladoria, 11 empresas atribuíram notas entre 4 e 5 a esta função.

Apenas duas empresas atribuíram notas de 1 a 3 para estas funções. Estas duas empresas têm gestão mista, possuem de 100 a 499 funcionários, são empresas de médio porte e tem tempo de fundação entre 10 e 20 anos, porém, suas respostas nas outras funções de controladoria não apresentam convergências.

Na Tabela 10 evidencia-se o grau de importância atribuído pelos respondentes à função de gestão da informação da controladoria nas empresas pesquisadas.

Tabela 10 - Função de gestão da informação

\begin{tabular}{|l|l|l|l|l|l|l|l|}
\hline Funções/Pontuação & Não Resp. & 1 & 2 & 3 & 4 & 5 & Total \\
\hline $\begin{array}{l}\text { Gerenciar as informações contábeis, patrimoniais, de custos, } \\
\text { gerenciais e estratégicas }\end{array}$ & 0 & 0 & 0 & 2 & 2 & 9 & 13 \\
\hline $\begin{array}{l}\text { Conceber o modelo do sistema de informações visando à } \\
\text { geração de informações gerenciais }\end{array}$ & 0 & 0 & 1 & 1 & 4 & 7 & 13 \\
\hline
\end{tabular}

Fonte: Dados da pesquisa.

Como descrito por Borinelli (2006, p. 139), "fazem parte das atividades de controladoria desenvolver, implementar e gerir os sistemas de informações, no que tange às informações contábeis, econômicas, financeiras e patrimoniais". 
Nesta função 11 empresas declararam grande importância. As duas empresas que declararam notas 2 e 3 para a gestão da informação são as mesmas que declararam baixa importância à função de controle de riscos.

Na Tabela 11 mostra-se o grau de importância atribuído pelos respondentes à função de controle operacional pela controladoria das empresas.

Tabela 11 - Função de controle operacional

\begin{tabular}{|l|l|l|l|l|l|l|l|}
\hline Funções/Pontuação & Não Resp. & 1 & 2 & 3 & 4 & 5 & Total \\
\hline $\begin{array}{l}\text { Controlar e auxiliar na definição dos parâmetros de rejeito/ } \\
\text { desperdício }\end{array}$ & 0 & 0 & 1 & 2 & 4 & 6 & 13 \\
\hline Monitorar e controlar volumes de produção & 0 & 0 & 2 & 2 & 5 & 4 & 13 \\
\hline Monitorar o gerenciamento da qualidade & 0 & 1 & 2 & 1 & 1 & 8 & 13 \\
\hline Acompanhar prazos de atendimento de pedidos & 0 & 2 & 2 & 0 & 1 & 8 & 13 \\
\hline
\end{tabular}

Fonte: Dados da pesquisa.

Observa-se na Tabela 11 que três das empresas respondentes declararam importância menor à função de controle operacional nas funções da controladoria. Estas empresas estão classificadas como empresas de médio porte, duas possuem de 100 a 499 funcionários e a outra possui mais de 500 funcionários, todas têm tempo de fundação superior a 10 anos e duas delas são de gestão mista.

A função de controle operacional pode estar descentralizada em algumas das empresas que atribuíram baixa pontuação ao serem questionados se esta é função da controladoria. Ela pode estar nestas empresas sob a responsabilidade dos gestores operacionais, já que "envolve detectar o que está acontecendo na operação, replanejando se necessário, e intervindo de modo a impor novos planos" (SLACK; CHAMBERS; JOHNSTON, 2002, p. 339).

Evidenciou-se que as respostas ficaram concentradas em todas as funções atribuídas à controladoria. Salvo as respostas de algumas empresas que em determinadas funções destoaram das demais. Pode-se inferir que existe um considerável grau de isomorfismo nas funções de controladoria entre as empresas pesquisadas.

\subsection{Redes de Isomorfismo nas Funções de Controladoria}

Para verificar a existência das redes de isomorfismo nas 13 empresas analisadas quanto às funções de controladoria elencadas anteriormente, procedeu-se o cálculo de uma função ponderada a partir das respostas relativas ao tópico anterior. Assim, almeja-se evidenciar as semelhanças das funções de controladoria presentes nessas empresas, conforme se apresenta na Figura 1. 
Figura 1 - Redes de isomorfismos nas funções de controladoria
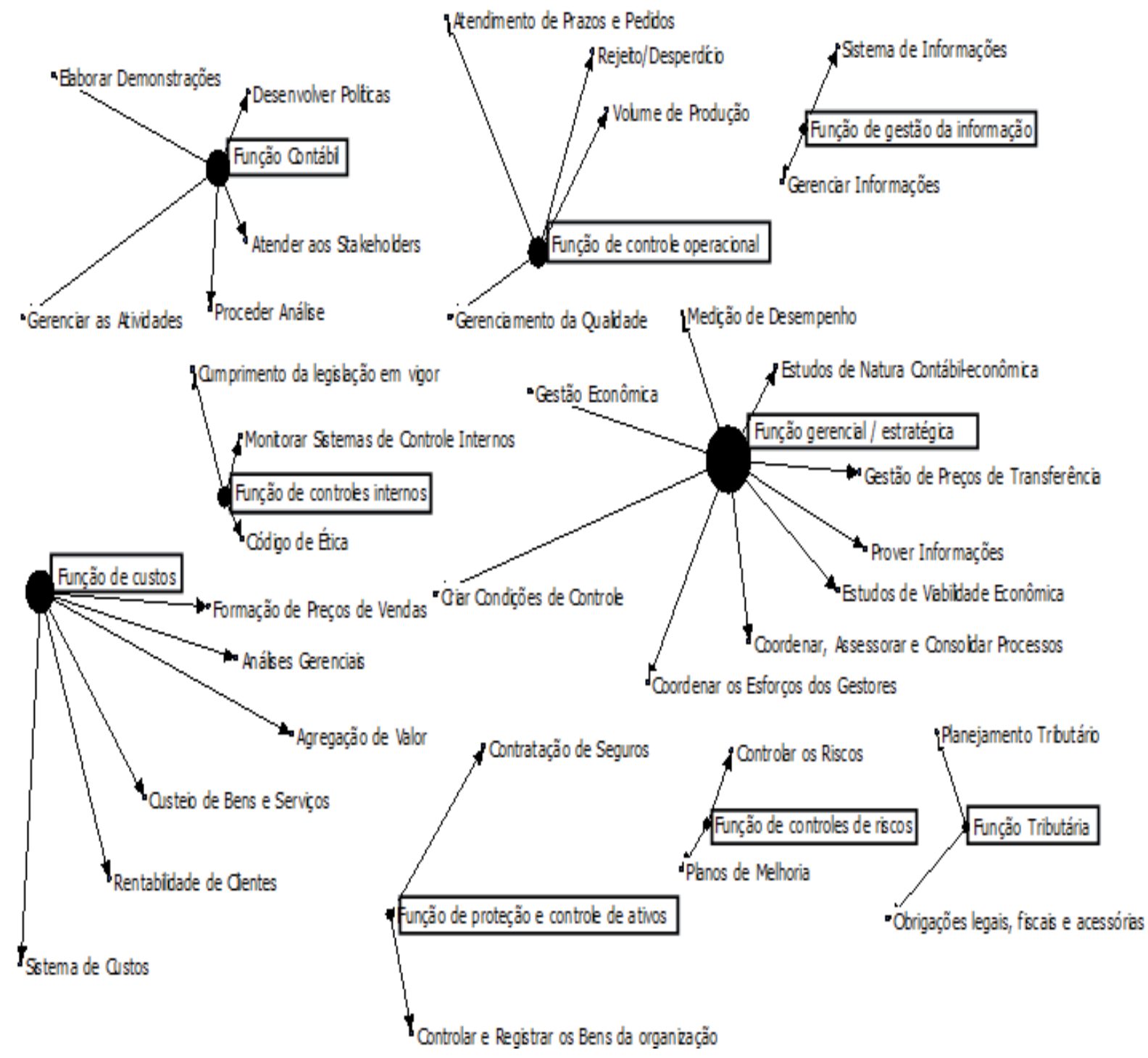

Fonte: Dados da pesquisa.

Na Figura 1 constata-se que a centralidade da rede de isomorfismos é ocupada pela função gerencial/estratégica, destacando-se pelo maior número de laços com suas respectivas atividades. Ocupando a segunda posição aparece a função de custos; e na terceira a função contábil. Em síntese, a função gerencial/ estratégica, a função de custos e a função contábil são ocupantes das posições centrais da rede de isomorfismos, o que denota que estas apresentam maior semelhança dentre as funções de controladoria analisadas. Os modos estabelecidos de administrar as funções organizacionais, de acordo com Kostova (1999), refletem o conhecimento compartilhado e a competência da organização. Elas tendem a ser legitimadas, aceitas e aprovadas pelo ambiente externo e empregadas como o modo certo de realizá-las internamente na organização.

Ainda, relativamente à rede de isomorfismo, percebe-se a predominância 
de laços fracos, pois as atividades que compõem as funções não estabelecem ligações entre si. Burt (1992 apud ESPEJO, 2009, p. 12) assevera que "a existência de lacunas fornece uma vantagem competitiva para o individuo que realiza a conexão entre as diferentes redes, haja vista que os indivíduos não conectados não possuem acesso antecipado, amplo e privilegiado às informações do outro grupo de pesquisadores". Nesse sentido, infere-se que as funções não realizam o compartilhamento de atividades, demonstrando a formação das lacunas estruturais.

Os resultados desta pesquisa apresentam semelhanças com os achados de Oyadomari et al. (2008b), que investigaram, à luz da Teoria Neo-Institucional, a adoção de artefatos de contabilidade gerencial no ambiente empresarial brasileiro. Com base nas respostas das 27 empresas de médio e grande porte pesquisadas, concluíram que o pilar cognitivo-cultural é o principal pilar para explicar a adoção dos controles gerenciais. Também observaram que a obtenção de desempenho econômico-financeiro caracteriza-se como um processo de legitimação, já que a alta competitividade do ambiente atual leva as organizações a buscarem um desempenho superior ao de seus competidores.

O pilar cognitivo-cultural nesta pesquisa pode estar associado à seleção das empresas objeto da pesquisa, que consistem de empresas familiares têxteis. A tradição do Estado de Santa Catarina no setor têxtil, o tempo de atuação no setor das empresas pesquisadas e a predominância de empresas com características familiares (CASILLAS; FERNANDEZ; SANCHEZ, 2007), certamente contribuem para a utilização de instrumentos isomórficos. Em se tratando da controladoria, que visa entre outros aspectos o desempenho econômico-financeiro da organização, não menos relevante é a busca de legitimação por meio de funções com este foco, como é o caso das funções gerencial/estratégica e de custos.

Posturas isomórficas em relação aos líderes do seu campo organizacional podem decorrer de diferentes motivações. A ausência de uma estrutura conceitual de controladoria, que defina o arcabouço das funções e atividades desta área organizacional, pode contribuir para um isomorfismo mimético nas empresas pesquisadas. Tal é corroborado em um estudo de Machado-da-Silva e Fonseca (1993), quando aduzem que a postura isomórfica entre empresas pode decorrer da necessidade de autodefesa diante de situações sem soluções geradas internamente. Portanto, diversas podem ser as explicações para adotar isomorfismos nas funções e atividades da controladoria.

\section{Conclusões}

O estudo objetivou verificar evidências de isomorfismo nas funções da controladoria das empresas familiares têxteis de Santa Catarina. Pesquisa descritiva por meio de levantamento foi realizada com abordagem qualitativa dos dados. 
Para o controller das empresas familiares associadas ao Sindicato das Indústrias de Fiação, Tecelagem e do Vestuário (Sintex) de Blumenau, Santa Catarina, foi enviado um questionário com perguntas fechadas, sendo que se obteve 13 respostas, constituindo-se na amostra não aleatória.

Os resultados da pesquisa evidenciam que as funções da controladoria, de modo geral, possuem grau de importância semelhante para as empresas pesquisadas. Há uma elevada concentração de respostas nos níveis 4 e 5 da escala de Likert. As funções relativas à gestão de risco e ao controle operacional apresentaram-se com grau mais elevado de diversidade nas respostas. Essas divergências podem decorrer do fato dessas funções estarem sendo relacionadas à controladoria há pouco tempo, inclusive pela literatura.

Em uma das empresas, no entanto, constatou-se baixo nível de importância para várias funções da controladoria, que além de possuírem respaldo no referencial teórico, foram consideradas relevantes pelos outros respondentes. As funções consideradas menos importantes nesta empresa têm características mais operacionais do que estratégicas. Em contato posterior com a empresa, verificouse que a controladoria tem efetivamente papel estratégico, está dissociada da contabilidade e da área fiscal e estas não estão subordinadas ao controller. Esta empresa tem uma estrutura bastante particular no que tange à controladoria.

Sobre a existência das redes de isomorfismo nas empresas analisadas quanto às funções de controladoria, procedeu-se ao cálculo de uma função ponderada a partir das respostas às questões do instrumento de pesquisa. A centralidade da rede de isomorfismos é ocupada pela função gerencial/estratégica, destacando-se pelo maior número de laços com suas respectivas atividades, e na sequência consta a função de custos, seguida da função contábil. Depreende-se que há consonância da centralidade nas redes de isomorfismos das funções gerencial/estratégica, de custos e contábil com os preceitos teóricos do que se caracteriza como papel da controladoria conforme pesquisa realizada por Borinelli (2006).

Assim conclui-se que há evidências de isomorfismo na maioria das funções da controladoria das empresas familiares pesquisadas, considerando-se o grau de importância atribuído pelos respondentes às atividades distribuídas nas nove funções apontadas. As funções gerencial/estratégica, custos e contábil ocuparam as posições centrais da rede de isomorfismos denotando maior semelhança entre as empresas analisadas. Portanto, os resultados da pesquisa denotaram semelhanças na percepção dos controlleres sobre o grau de importância das funções de controladoria nas empresas estudadas.

Embora não se tenha constituído em objetivo deste estudo encontrar explicações para os isomorfismos observados, especula-se que as funções da controladoria ocupantes das posições centrais das redes de isomorfismos assim se configuram devido ao pilar cognitivo-cultural. Destacam-se neste aspecto a 
tradição no setor das empresas da região pesquisada, a experiência destas empresas no ramo têxtil, as características de gestão familiar e a ausência de uma estrutura conceitual da controladoria. Dimaggio e Powell (1991) ressaltam que o ambiente é um fator de homogeneização organizacional, na medida em que práticas e formas de organização são difundidas e institucionalizadas pela comunidade de organizações pertencentes a um mesmo setor econômico.

Apesar das evidências de isomorfismo em funções da controladoria nas empresas pesquisadas, não é possível generalizar as conclusões. E como sugestão de pesquisa, poder-se-ia estudar a influência do modelo de gestão adotado pelas empresas familiares nas funções da controladoria. Durante a análise dos dados também surgiu o questionamento sobre a relação do surgimento destas empresas nas décadas passadas e o movimento de redução da força de trabalho nas grandes empresas têxteis naquele período, que é também uma sugestão de pesquisas futuras.

\section{Referências}

ALMEIDA, Lauro Brito; PARISI, Cláudio; PEREIRA, Carlos Alberto. Controladoria. In: CATELLI, Armando (Org.). Controladoria: uma abordagem da gestão econômica - GECON. 2. ed. São Paulo: Atlas, 2001.

ARIMA, Carlos Hideo. Sistemas de informações gerenciais. In: SCHMIDT, Paulo (Org). Controladoria: agregando valor para a empresa. Porto Alegre: Bookman/ Artmed, 2002.

CARPENTER, Vivian L.; FEROZ, Ehsan H. Institutional theory and accounting rule choice: an analysis for four US state governments' decisions to adopt generally accepted accounting principles. Accounting, Organizations and Society, v. 26, n.7-8, p. 565-596, 2001.

BEUREN, Ilse Maria. O papel da controladoria no processo de gestão. In: SCHMIDT, Paulo (Org). Controladoria: agregando valor para a empresa. Porto Alegre: Bookman/Artmed, 2002.

BORINELLI, Marcio Luiz. Estrutura Conceitual Básica de Controladoria: sistematização à luz da teoria e da práxis. 2006. Tese (Doutorado em Ciências Contábeis). Programa de Pós-graduação em Ciências Contábeis, Departamento de Contabilidade e Atuária, Faculdade de Economia, Administração e Contabilidade da Universidade de São Paulo, 2006.

CASILLAS BUENO, José Carlos; FERNANDEZ, Carmen Diaz; SANCHEZ, 
Adolfo Vázques. Gestão da empresa familiar: conceitos, casos e soluções. São Paulo: Thompson Learning, 2007.

CERVO, Amado Luiz; BERVIAN, Pedro Alcino. Metodologia científica. 5. ed. São Paulo: Prentice Hall, 2002.

DIMAGGIO, Paul. J.; POWELL, Walter. W. The Iron cage revisited: institutional isomorphism and collective rationality. In: POWELL, W. W.; DiMAGGIO, P. J. (Org.). The new institutionalism in organizational analysis. Chicago: University of Chicago Press, 1991.

ESPEJO, Márcia Maria dos Santos Bortolocci et al. Campo de pesquisa em contabilidade: uma análise de redes sob a perspectiva institucional. In: IAAERANPCONT, 3., 2009, São Paulo. Anais... São Paulo: IAAER-ANPCONT, 2009. CD-ROM.

FERNANDES, Francisco Carlos. Uma contribuição à estruturação da atividade de controladoria em entidades fechadas de previdência privada: uma abordagem da gestão econômica. 2000. Tese (Doutorado em Ciências Contábeis) - Programa de Pós-graduação em Ciências Contábeis, Departamento de Contabilidade e Atuária, Faculdade de Economia, Administração e Contabilidade da Universidade de São Paulo, 2000.

FIGUEIREDO, Sandra; CAGGIANO, Paulo Cesar. Controladoria: teoria e prática. São Paulo: Atlas, 1992.

FREITAS, Carlos Alberto Sampaio de. Aprendizagem, isomorfismo e institucionalização: o caso da atividade de auditoria operacional no Tribunal de Contas da União. 2005. Dissertação (Mestrado em Administração) - Programa de PósGraduação em Administração da Universidade de Brasília, 2005.

GIONGO, Juliano; NASCIMENTO, Auster Moreira. O envolvimento da controladoria no processo de gestão: um estudo em empresas industriais do estado do Rio Grande do Sul. In: CONGRESSO INTERNACIONAL DE CUSTOS, 9., 2005, Florianópolis. Anais... São Leopoldo/RS: Associação Brasileira de Custos, 2005. CD-ROM.

KANITZ, Stephen Charles. Controladoria: teoria e estudo de casos. São Paulo: Pioneira, 1976.

KOSTOVA, Tatiana. Success of the transnational transfer of organizational practices within multinational companies. International Business Program Area College of Business Administration of University of South Carolina. Briarcliff 
Manor, v. 24, n. 2, p. 308, 1999.

LODI, João Bosco. A empresa familiar. 2. ed. São Paulo: Pioneiras, 1986.

MACHADO-DA-SILVA, C. L.; FONSECA, V. S. Homogeneização e diversidade organizacional: uma visão integrativa. In: ENANPAD, 23., Salvador, 1993. Anais... Rio de Janeiro: ANPAD, 1993.

MARTIN, Nilton Cano. Da contabilidade à controladoria: a evolução necessária. Revista Contabilidade \& Finanças. V. 13, n. 28, p. 7-28, jan./abr. 2002.

MARTINS, Gilberto de Andrade; THEÓPHILO, Carlos Renato. Metodologia da investigação científica para ciências sociais aplicadas. São Paulo: Atlas, 2007.

MOSIMANN, Clara Pellegrinello; FISCH, Silvio. Controladoria: seu papel na administração de empresas. 2. ed. São Paulo: Atlas, 1999.

OLIVEIRA, Luís Martins de; PEREZ Jr., José Hernandez; SILVA, Carlos Alberto dos Santos. Controladoria estratégica. 4. ed. São Paulo: Atlas, 2007.

OYADOMARI, José Carlos Tiomatsu; MENDONÇA NETO, Octavio Ribeiro de; CARDOSO, Ricardo Lopes; FREZATTI, Fábio. Análise dos fatores que favorecem a institucionalização da Value Based Management (VBM) à luz dos argumentos de teóricos da vertente New Institutional Sociology (NIS ). Revista Universo Contábil, v. 4, n. 2, p. 06-21, abr./jun. 2008a.

OYADOMARI, José Carlos Tiomatsu; MENDONÇA NETO, Octavio Ribeiro de; CARDOSO, Ricardo Lopes; LIMA, Mariana Ponciano de. Fatores que influenciam a adoção de artefatos de controle gerencial nas empresas brasileiras: um estudo exploratório sob a ótica da Teoria Institucional. Revista de Contabilidade e Organizações, v. 2 n. 2, p. 55-70, jan./abr. 2008.

ORO, Ieda Margarete. Avaliação da eficiência de empresas familiares brasileiras utilizando a análise envoltória de dados. 2006. 168 f. Dissertação (Mestrado em Ciências Contábeis) - Curso de Pós- Graduação em Ciências Contábeis, Universidade Regional de Blumenau, Blumenau, 2006.

PELEIAS, Ivam Ricardo. Controladoria: gestão eficaz utilizando padrões. São Paulo: Saraiva, 2002.

PETRY, Luiz Inácio. Um estudo sobre o modelo de gestão e o processo sucessório em empresas familiares. 2005. 255 f. Dissertação (Mestrado em Ciências Contábeis) - Curso de Pós- Graduação em Ciências Contábeis, Universidade do 
Vale do Rio dos Sinos, São Leopoldo, 2005.

RICARDINO FILHO, Alvaro Augusto. Retrospectiva histórica sobre um profissional chamado controller. In: CONGRESSO INTERNACIONAL DE CUSTOS, 6 , Braga/ Portugal, 1999. Anais... Braga/Portugal, Universidade do Minho, 1999.

SLACK, Nigel; CHAMBERS, Stuart; JOHNSTON, Robert. Administração da produção. 2 ed. São Paulo: Atlas, 2002.

TOLBERT, P. S.; ZUCHER, L. G. A institucionalização da teoria institucional. In: CALDAS, M.; FACHIN, R.; FISCHER, T. (Orgs.). Handbook de Estudos Organizacionais: modelos de análise e novas questões em estudos organizacionais. São Paulo: Atlas, 1999. 